\title{
Improving material efficiency in the life cycle of products: a review of EU Ecolabel criteria
}

\author{
Mauro Cordella $^{1} \cdot$ Felice Alfieri $^{1} \cdot$ Javier Sanfelix $^{1} \cdot$ Shane Donatello $^{1} \cdot$ Renata Kaps $^{1} \cdot$ Oliver Wolf $^{1}$
}

Received: 27 September 2018 / Accepted: 3 March 2019 / Published online: 16 March 2019

(C) The Author(s) 2019

\begin{abstract}
Purpose Material efficiency encompasses a range of strategies that support a reduction of material consumption and waste production from a product's life cycle perspective and which can help the transition towards a circular economy. The aim of this paper is to analyse the state of implementation of material efficiency requirements for products as set out in existing EU Ecolabel criteria, consider possible improvements, identify current limitations and describe potential or existing synergies with other EU policies and initiatives.

Methods Key concepts related to material efficiency have been provided and classified into three groups which are, in order of decreasing priority: reduction, reuse, and recycling/recovery. This classification system has then been used for the analysis of existing requirements set out for different EU Ecolabel products. This includes a description of potential environmental benefits, trade-offs, market barriers and risks. Material efficiency concepts have then been cross-checked with other EU policies and initiatives.

Results and discussion Looking at EU Ecolabel criteria for 26 different product groups revealed a broad range of material efficiency aspects, some of which are influenced by the nature of the product group itself. Some material efficiency aspects were broadly integrated into EU Ecolabel criteria through complementary strategies (e.g. design for durability, recyclability, availability of spare parts, reversible disassembly and provision of information). However, ways to implement additional material efficiency requirements (e.g. minimum lifetime of products) should be sought further. A symbiotic relationship can exist between the EU Ecolabel and many policy tools in the sense that regulatory and standardisation frameworks can offer a robust basis for justifying the integration of material efficiency aspects in the EU Ecolabel, while the EU Ecolabel can explore and promote approaches targeted at front runners in material efficiency aspects in a voluntary manner.

Conclusions The experience gained from implementing material efficiency aspects in the EU Ecolabel could serve as a reference for shaping design, communication or policy initiatives aimed at the promotion of a more circular economy. Attempts to quantify the impacts from material efficiency measures should be also integrated systematically in future research, with the support of tools like life cycle assessment. However, additional considerations of political, technical and socio-economic nature must be considered when assessing the relevance, feasibility and ambition level of any material efficiency-related requirements.
\end{abstract}

Keywords Circular economy $\cdot$ EU Ecolabel $\cdot$ Life cycle $\cdot$ Material efficiency $\cdot$ Product policy $\cdot$ Requirements

\section{Introduction}

The intention of the European Commission (EC) to transform Europe's economy into a more sustainable one is reflected

Responsible editor: Fabio Iraldo

Mauro Cordella

mauro.cordella@ec.europa.eu

1 European Commission, Circular Economy and Industrial Leadership Unit, Joint Research Centre (JRC), Seville, Spain through its environmental policy. Already twenty years ago, the EC recognised the need to develop product-focused environmental policy (Ernst and Young 1998). In 2003, a communication on Integrated Product Policy (IPP) (EC 2003) was adopted which outlined strategies for decreasing environmental impacts from products throughout their life cycle. The IPP effectively introduced the "life cycle thinking approach" where the environmental impacts of products should be considered from "the cradle to the grave", and in an integrated manner. In this way, the shifting of environmental burdens between different life cycle stages or sectors can be avoided and policy coherence when dealing with the diverse impacts 
of production and consumption can be ensured. The IPP was followed by the Ecodesign Directive on energy-using products (EC 2005a, 2009a) and by the Sustainable Consumption and Production Action Plan (EC 2008a), which focused on how to improve the environmental performance of products and technologies and foster well-informed decisions by consumers. Product policies based on life cycle thinking were therefore developed. However, as no single policy can be capable of addressing all product and sector specific challenges, it was recognised that a combination of pull (voluntary) and push (mandatory) tools is needed (see Fig. 1).

The common denominator for policy tools is that they regulate environmental aspects for different life cycle stages of products. However, their scope and intended ambition levels differ. While Ecodesign (EC 2005a, 2009a) serves to push the market towards more sustainable products through the implementation of mandatory minimum requirements, Green Public Procurement (GPP) (EC 2008b) and EU Ecolabel criteria (EC 2010) aim to pull the market by promoting the production and consumption of more sustainable product options. In particular, the Ecolabel is a type-I environmental label (ISO 2018) that can bring added value for companies that invest in eco-innovation and want to communicate the improved environmental performance of their products or services to consumers (Iraldo and Barberio 2017). In contrast, the Energy Label (EC 2017a) applies to the entire spectrum of relevant products and allows consumers to choose between different product performance levels.

Life cycle assessment (LCA) (ISO 2006a, b) is a key tool to identify how environmental requirements should be developed and to understand any related impacts and trade-offs (Cordella et al. 2015; Cordella and Hidalgo 2016). In general, this needs to be embedded in a broader analysis of legislative, techno-economic and social aspects (e.g. product quality, inherent safety of materials (Cordella et al. 2009; Cordella et al. 2012)) that are not conventionally covered or fully integrated in LCA. More recently, the Product Environmental Footprint (PEF) guide (EC 2013a) has developed harmonised rules for quantifying relevant environmental impacts of products through their life cycle. A pilot phase has been conducted to test the process for developing product and sector category rules, approaches for verification and vehicles for communicating the environmental performance of products (EC 2013b).

To date, Ecodesign and Energy Label are mandatory tools which have been specifically targeted at energy-using and energy-related products with a particular focus on energy consumption during the use phase. EU Ecolabel and GPP generally have a much wider scope both in terms of products and type of requirements, which in part stems from their voluntary nature. These tools can cover the production site (e.g. emissions to air and water, energy consumption), product composition (e.g. exclusion of certain substances due to their inherent hazardous properties), use phase (e.g. energy efficiency, fitness for use), or the end of life (e.g. design for ease of recycle). Service aspects such as take-back and repair can also be relevant, especially in GPP.

The recent Circular Economy Action Plan (EC 2015a), which promotes transition in the EU towards a more circular economy, has remarked the importance of material efficiency requirements in discussions about product sustainability. However, effort is needed to stimulate the systematic and coherent implementation of material efficiency aspects in product policy tools. To this end, the European Commission issued Mandate 543 (EC 2015b) to CEN/CENELEC to develop standards with which to harmonise concepts, methods and
Fig. 1 Product policy tools and sustainability of products on the market

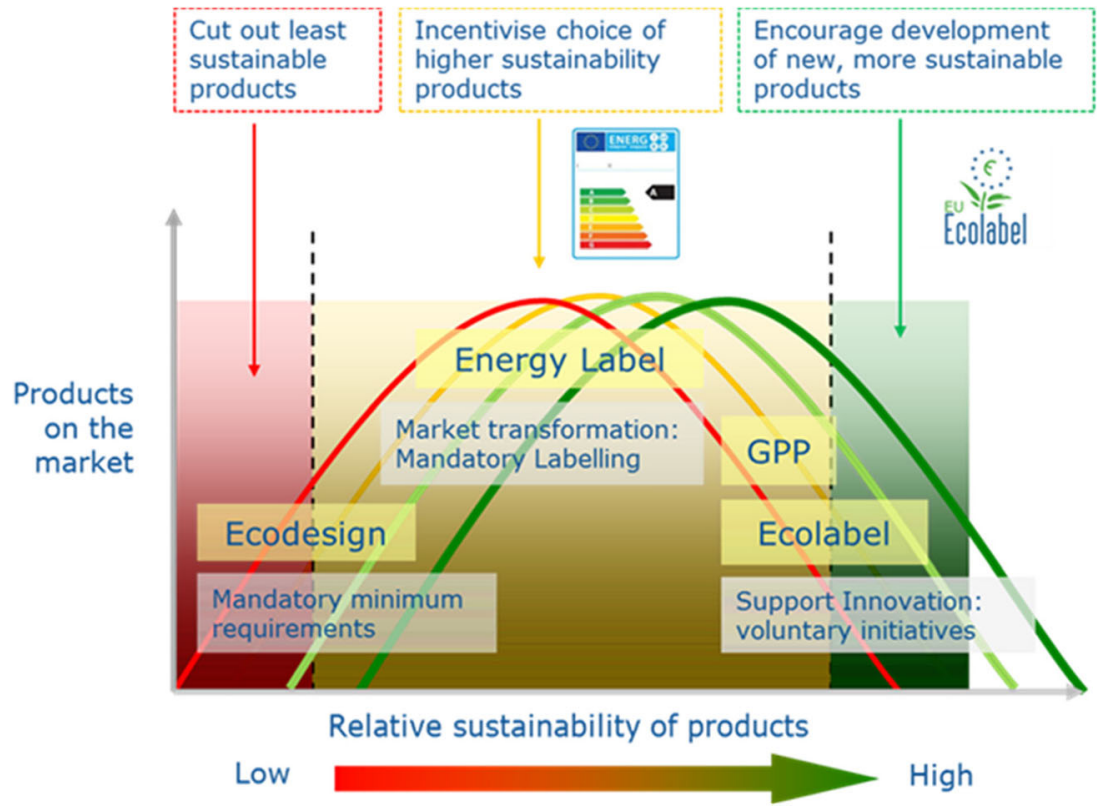


nomenclatures to apply in the assessment of material efficiency aspects of energy-related products (CEN/CLC/JTC 10 2019).

The goal of this paper is to analyse existing material efficiency requirements set for EU Ecolabel products. A definition and classification system is presented to support a coherent discussion of such aspects in a hierarchically structured way. Current practice, limitations and possible improvements are described, as well as potential synergies with other EU policies and initiatives. As a voluntary tool targeting frontrunners, an analysis of the EU Ecolabel criteria can provide a reference base and a potential benchmark for design, communication and policy activities aimed at promoting the material efficiency of products and contributing to the implementation of a more circular economy.

\section{Methods}

In order to analyse to what extent material efficiency aspects are recognised by the EU Ecolabel and how this could be potentially improved, it is first necessary to have a clearer understanding of what is meant by the term "material efficiency", then to use this definition to screen against a defined number of EU Ecolabel product groups, and finally to cross-check against other EU policies and legislation to identify possible synergies or barriers to further the promotion of material efficiency-related criteria.

\subsection{Definition and classification of material efficiency aspects}

The analysis of material efficiency aspects entails dealing with a broad spectrum of concepts. Analogous to the definition of "energy efficiency" (EC 2012a), "material efficiency" can be defined as the ratio between the performance output of a product, service or energy system and the input of materials required to provide such output. It is thus apparent that material efficiency can increase either by improving the performance or reducing the input of materials to provide a certain performance.

From a system perspective, material efficiency can be considered a range of strategies relating to the use and management of resources throughout the life cycle of a product or service and which aims to minimise material consumption, waste production and their related environmental impacts (Allwood et al. 2011; Huysman et al. 2015), without affecting functionalities negatively.

Figure 2 shows alternative routes for products before their final disposal in landfill, which can contribute to improving their material efficiency. At the macro-scale level, material efficiency can mean moving from a linear model of production and consumption (i.e. from virgin material extraction, to short/single use of products and final disposal in landfill) to a more circular model, where input of virgin materials can be reduced and landfill disposal is minimised, or at least kept controlled in a growing economy. A framework of indicators which could be potentially used to quantify such a transition at different levels has been presented in Huysman et al. (2015).

Material efficiency strategies can be quite well mirrored by the hierarchical approach set out by the Waste Framework Directive (Allwood et al. 2011; Bakker et al. 2014; EC 2008c, 2018a), as shown in Fig. 3. The waste hierarchy aims at reducing the waste output and its disposal in landfill. Material efficiency goes beyond and promotes also the prevention of material consumption. Taking the example of waste management, a hierarchy of strategies has been drawn for material efficiency aspects at the product level:

1. Reduction: the highest priority can be assigned to the direct reduction of the quantity of materials used for products and services. This can be promoted through design and manufacturing practices which address

(a) The material resources used in products, e.g. through the integration of functionalities (e.g. multifunctional devices allowing printing and scanning), the dematerialisation of products and services, the avoidance of design over-specifications, and design optimisation and lightweighting processes (Allwood et al. 2011), as done already in the car industry (Traverso et al. 2013). The use of recycled materials has been addressed in the third category related to recycling because it affects the consumption of virgin materials at the system level, but does not necessarily imply a reduction in the mass of the product.

(b) A more efficient use of material resources in the manufacturing process (Allwood et al. 2011), including the minimisation of the manufacturing waste.

2. Reuse: this category aims at prolonging the use of products, or parts of products, preventing the need for new products and ultimately saving material resources and avoiding waste production (Bakker et al. 2014), due to the prolongation of the lifetime of a product or of its parts. This can be promoted through the consideration of a range of design aspects allowing the retention of product value by

(a) Making products/parts more durable (e.g. enhancing resistance and duration under defined conditions of use (Alfieri et al. 2018a, b)).

(b) Facilitating repair, reuse and upgrade (RRU) operations (Cordella et al. 2018), as well as refurbishment and remanufacturing processes (Russell 2018).

3. Recycling/recovery: as a last option, the residual value of products and materials can be recovered at the end of life 
Fig. 2 Material efficiency aspects in the context of a product life cycle

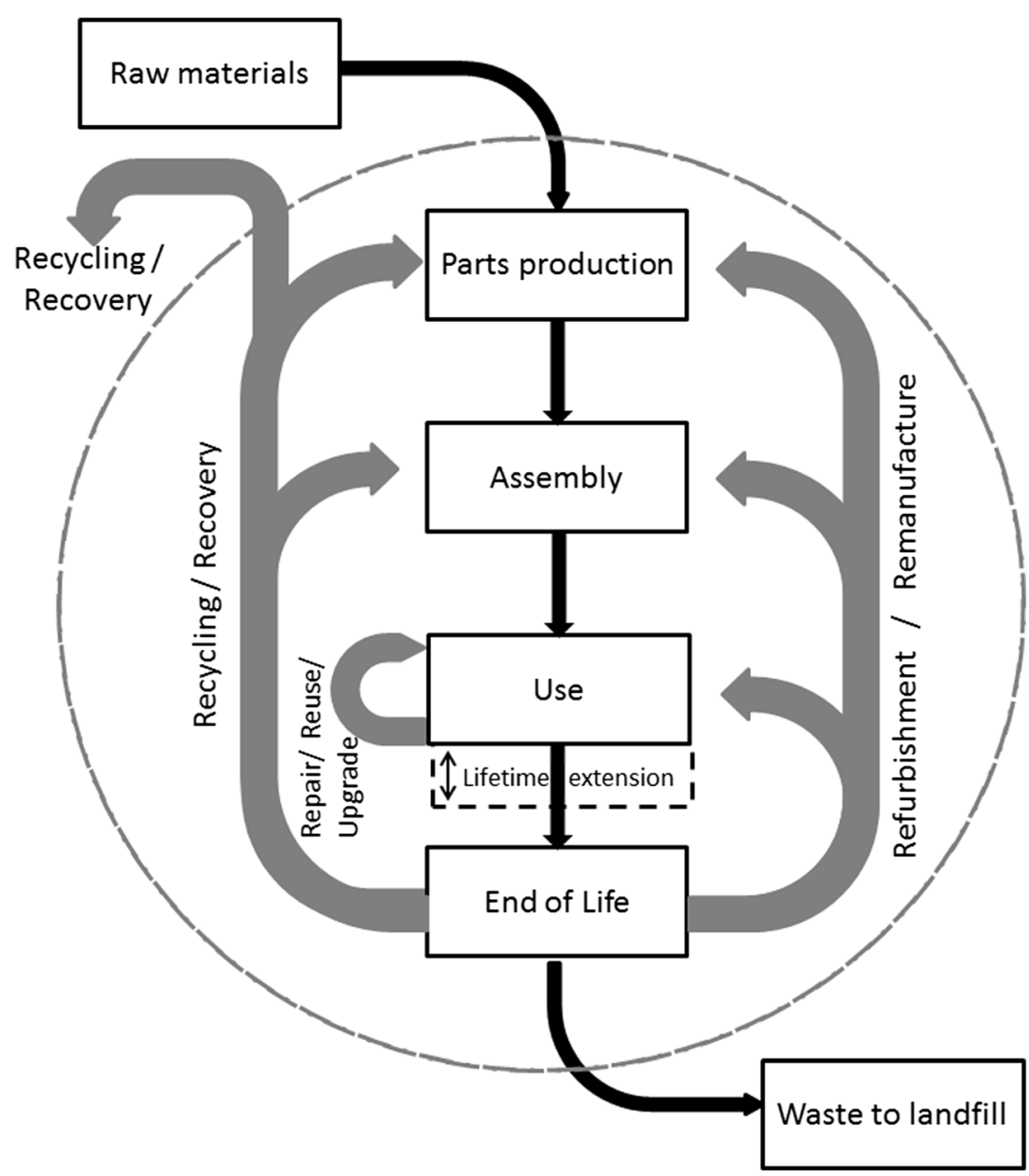

Fig. 3 Analogy between waste and material efficiency hierarchies

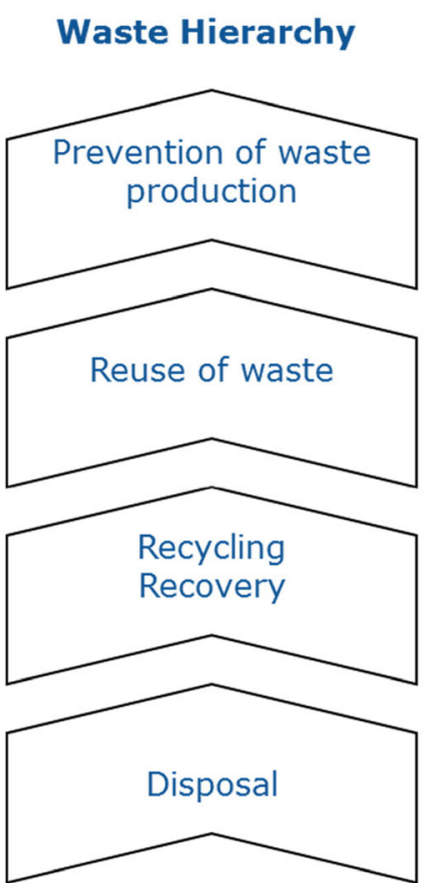

\section{Material Efficiency} Hierarchy

Best Option

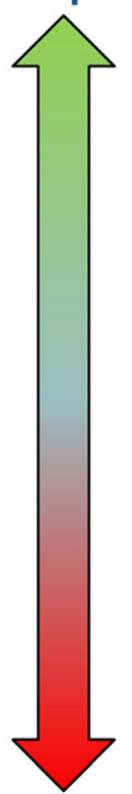

Worst Option 
through recycling and recovery processes. Recycling is beneficial since it can reduce the consumption of virgin materials. A distinction between non-destructive and destructive (conventional) recycling can be made depending if the targets of the recycling operation are parts or materials, respectively (Allwood et al. 2011). Destructive recycling requires dismantling of the product to separate its material constituents and reprocessing recyclates prior to their re-entry into the material supply chain (e.g. paper to be deinked and pulped, plastics to be re-melted and extruded, steel to be smelted). For the parts where recycling is not feasible, waste materials should be recovered as far as possible for other purposes, such as energy production. Annex II of the Waste Framework Directive (EC 2008c, 2018a) sets out a non-exhaustive list of recovery operations. In any case, waste has to undergo safe disposal operations (see Annex I of the Waste Framework Directive), which may require selective treatments, as in the case of electronic waste (EC 2012b). Reusability/recyclability/recoverability (RRR) rates can be used to indicate the percentage of the mass of a product that is expected to be reused/recycled/recovered at the end of life (Huysman et al. 2015). Recycling and recovery can be promoted by

(a) Design approaches aimed at improving the recyclability of products.

(b) An increase in the target content of recycled materials in products.

(c) The implementation of take-back systems to return products at the end of life.

The classification presented above has been applied for the clustering and analysis of EU Ecolabel requirements on material efficiency. Since the terminology specifically used to describe material efficiency aspects has evolved separately in different sectors, a series of relevant terms used in this analysis is defined in Table 1.

Table 1 Definitions of specific terms related to material efficiency aspects as used in this work

\begin{tabular}{|c|c|}
\hline Term & Definition \\
\hline Disassembly & The process by which a product can be separated into its parts in a non-destructive way. \\
\hline Dismantling & The process by which a product can be separated into its parts and materials in a destructive way. \\
\hline Durability & $\begin{array}{l}\text { The ability of a product to function as required under defined conditions of use and maintenance until a limiting } \\
\text { state due to a technical failure is reached. } \\
\text { Note: a broader definition of durability could include repair, upgrade and socio-economic considerations. }\end{array}$ \\
\hline Lightweighting & $\begin{array}{l}\text { The reduction of the quantity of materials in a product without compromising its ability to meet its minimum } \\
\text { functional requirements. }\end{array}$ \\
\hline Manufacturing waste minimisation & The reduction of the waste produced during the manufacture of a product that is not reused, recycled or recovered. \\
\hline Recoverability & The degree to which parts can be separated at end of life (for depollution, reuse or energy purposes). \\
\hline Recovery & $\begin{array}{l}\text { Operations by which waste materials are reprocessed into products, materials or substances used for the original or } \\
\text { other purposes. }\end{array}$ \\
\hline Recyclability & The degree to which a product contains materials that can be separated and recycled at the end of life. \\
\hline Recycle & $\begin{array}{l}\text { Recovery operation by which waste materials are reprocessed into products, materials or substances used whether } \\
\text { for the original or other purposes, excluding backfilling and energy production. }\end{array}$ \\
\hline Refurbishment & $\begin{array}{l}\text { Treatment or a modification of a product, or parts of a product, to increase or restore its performance and/or } \\
\text { functionality or to meet applicable technical standards or regulatory requirements, with the result of making a } \\
\text { fully functional product to be used for a purpose that is at least the one that was originally intended. }\end{array}$ \\
\hline Remanufacturing & $\begin{array}{l}\text { The treatment or modification of a product, or parts of a product, in industrial processes to restore it to original as } \\
\text { new condition and performance, or better. This is done in line with specific technical specifications, including } \\
\text { engineering, quality and testing standards, and typically yields fully warranted products. }\end{array}$ \\
\hline Repair & The process of returning a faulty product, or a part of a product, to a condition where it can fulfil its intended use. \\
\hline Reparability & The ease with which a product/part can be repaired. \\
\hline Reusability & The potential for a product, or its parts, to be reused by another user and for the same purpose. \\
\hline Reuse & $\begin{array}{l}\text { Operation by which a product, or its parts, continue to be used for the same purpose for which they were } \\
\text { conceived. }\end{array}$ \\
\hline RRU & Reparability, reusability and upgradability. \\
\hline Upgradability & The ease with which a product/part can be upgraded. \\
\hline Upgrade & The process of enhancing the functionality, performance, capacity or aesthetics of a products or a part of a product. \\
\hline
\end{tabular}


It should be noted that the EU Ecolabel covers also other aspects that go beyond the scope of this paper, such as fitness for use, emissions to air/water and energy consumption in the use phase. In particular, fitness for use refers to the suitability of a product to fulfil its intended functions and purposes (e.g. for detergents, it would be its effectiveness to remove dirt from laundry up to an acceptable standard). Fitness for use could be considered as relevant for material efficiency since it could reduce the likelihood of consuming more product units for the same purpose (e.g. in the case of diapers and tissue papers with reduced absorbency). However, this has not been explicitly included in the analysis since it is a minimum entry level requirement that any EU Ecolabel product has to comply with in order to ensure the satisfactory performance and quality of products.

\subsection{Products included in the analysis}

In September 2018, the EU Ecolabel applied to 26 different product groups and counted with more than 2000 valid licences covering over 70,000 products and services available on the market (EC 2018b). All product groups are analysed, which can be split into five macro-categories of products (see Table 2):

1. Energy-using products

2. Multi-material products

3. Biomass-based products

4. Products that are mixtures

5. Products that are services

Table 2 Screening of EU Ecolabel requirements for material efficiency aspects

\begin{tabular}{|c|c|c|c|c|c|c|c|c|}
\hline \multirow[t]{2}{*}{ Product group } & & \multicolumn{2}{|l|}{ Reduction } & \multicolumn{2}{|l|}{ Reuse } & \multicolumn{3}{|c|}{ Recycling/recovery } \\
\hline & & $\begin{array}{l}\text { Use of } \\
\text { material } \\
\text { resources }\end{array}$ & $\begin{array}{l}\text { Manufacturing } \\
\text { waste } \\
\text { minimisation }\end{array}$ & Durability & RRU & Recyclability & $\begin{array}{l}\text { Recycled } \\
\text { content }\end{array}$ & $\begin{array}{l}\text { Take- } \\
\text { back } \\
\text { system }\end{array}$ \\
\hline \multirow{3}{*}{$\begin{array}{l}\text { Energy-using } \\
\text { products }\end{array}$} & Computers (EC 2016a) & & & $\mathrm{x}$ & $\mathrm{x}$ & $\mathrm{x}$ & $\mathrm{x}$ & \\
\hline & Televisions (EC 2009b) & & & & $\mathrm{x}$ & $\mathrm{x}$ & & \\
\hline & Water-based heaters (EC 2014a) & & & & $\mathrm{x}$ & $\mathrm{x}$ & & $\mathrm{x}$ \\
\hline \multirow{6}{*}{$\begin{array}{l}\text { Multi-material } \\
\text { products }\end{array}$} & Absorbent hygiene products (EC 2014b) & & $\mathrm{x}$ & & & & & \\
\hline & Bed mattresses (EC 2014c) & & & $\mathrm{x}$ & $\mathrm{x}$ & $\mathrm{x}$ & & \\
\hline & Footwear (EC 2016b) & & & $\mathrm{x}$ & & & $\mathrm{x}$ & \\
\hline & Furniture (EC 2016c) & & & $\mathrm{x}$ & $\mathrm{x}$ & $\mathrm{x}$ & $\mathrm{x}$ & \\
\hline & Hard coverings (EC 2009c) & & $\mathrm{x}$ & & & & $\mathrm{x}$ & \\
\hline & Textiles (EC 2014d) & & & $\mathrm{x}$ & & & $\mathrm{x}$ & \\
\hline \multirow{5}{*}{$\begin{array}{l}\text { Biomass-based } \\
\text { products }\end{array}$} & Converted paper (EC 2014e) & & $\mathrm{x}$ & & & $\mathrm{x}$ & $\mathrm{x}$ & \\
\hline & $\begin{array}{l}\text { Graphic paper, tissue paper and tissue } \\
\text { products* (EC 2019) }\end{array}$ & & & & & & $\mathrm{x}$ & \\
\hline & Printed paper (EC 2012c, 2012d) & & $\mathrm{x}$ & & & $\mathrm{x}$ & $\mathrm{x}$ & \\
\hline & $\begin{array}{l}\text { Soil improvers and growing media (EC } \\
2015 \mathrm{c} \text { ) }\end{array}$ & & & & & & $\mathrm{x}$ & $\mathrm{x}$ \\
\hline & $\begin{array}{l}\text { Wood-, cork- and bamboo-based floor cov- } \\
\text { erings (EC 2017b) }\end{array}$ & & & $\mathrm{x}$ & $\mathrm{x}$ & & $\mathrm{x}$ & \\
\hline \multirow{9}{*}{$\begin{array}{l}\text { Products that are } \\
\text { mixtures }\end{array}$} & Detergents for dishwashers (EC 2017c) & $\mathrm{x}$ & & & & $\mathrm{x}$ & $\mathrm{x}$ & \\
\hline & Hand dishwashing detergents (EC 2017d) & $\mathrm{x}$ & & & & $\mathrm{x}$ & $\mathrm{x}$ & \\
\hline & Hard surface cleaning products (EC 2017e) & $\mathrm{x}$ & & & & $\mathrm{x}$ & $\mathrm{x}$ & $\mathrm{x}$ \\
\hline & Industrial dishwasher detergents (EC 2017f) & $\mathrm{x}$ & & & & $\mathrm{x}$ & $\mathrm{x}$ & $\mathrm{x}$ \\
\hline & Industrial laundry detergents (EC 2017g) & $\mathrm{x}$ & & & & $\mathrm{x}$ & & $\mathrm{x}$ \\
\hline & Laundry detergents (EC 2017h) & $\mathrm{x}$ & & & & $\mathrm{x}$ & $\mathrm{x}$ & \\
\hline & Lubricants (EC 2018c) & & & & & & $\mathrm{x}$ & \\
\hline & Paints and varnishes (EC 2014f) & $\mathrm{x}$ & & $\mathrm{x}$ & & & & \\
\hline & Rinse Off Cosmetics (EC 2014g) & $\mathrm{x}$ & & & & $\mathrm{x}$ & & \\
\hline \multirow{2}{*}{$\begin{array}{l}\text { Products that are } \\
\text { services }\end{array}$} & Indoor cleaning services (EC 2018d) & $\mathrm{x}$ & & & & $\mathrm{x}$ & & \\
\hline & Tourist accommodation services (EC 2017i) & $\mathrm{x}$ & $\mathrm{x}$ & $\mathrm{x}$ & $\mathrm{x}$ & $\mathrm{x}$ & & \\
\hline
\end{tabular}

*In January 2019, the EU Ecolabel for graphic paper and for tissue paper and tissue products were published in a single Decision with two annexeshence, 25 product groups are listed above instead of 26 


\subsection{Cross-check with EU policies and initiatives}

Once the review of the material efficiency aspects currently promoted by the EU Ecolabel has been carried out, other EU policies and initiatives need to be considered in order to identify any possible synergies and barriers that would encourage or discourage further promotion of material efficiency, as well as legislation that could make material efficiency redundant.

The product policies and initiatives considered are GPP (EC 2008b), Ecodesign (EC 2009a), Energy Label (EC 2017a) and the Product Environmental Footprint (EC 2013a).

In addition, the analysis also include the Circular Economy Action Plan (EC 2015a), legislation on safety (EC 2001, 2006a, 2014h), hazardous substances (EC 2004, 2006b, 2008d, 2011a), consumer rights (EC 1999, 2011b) and products' end of life (EC 2008c, 2012b, 2018a), as well as more specific product-related topics (packaging (EC 1994), priority materials (EC 2017j, 2017k), batteries (EC 2006c) and vehicles (EC 2000, 2005b, 2011c)).

\section{Material efficiency aspects in the EU Ecolabel}

In accordance with the approach presented in section 2, material efficiency requirements that products have to fulfil to be awarded the EU Ecolabel have been categorised as shown in Table 2. Further details can be found in the Commission Decisions referenced in the table. An overview of how material efficiency strategies could be systematically addressed in the EU Ecolabel is shown in Table 3.

\subsection{Reduction}

Material efficiency options currently implemented in EU Ecolabel requirements for this strategy typically cover lightweighting, efficiency of use and minimisation of the production waste.

Lightweighting aspects are mainly associated with product groups that are mixtures. A closer look at detergents and for rinse-off cosmetics reveals that all these product groups have requirements on packaging efficiency (e.g. a maximum limit of weight of packaging per volume of product). Even though the LCA results did not reveal packaging as a significant contributor to overall environmental impacts, still the packaging was considered important due to high overall amounts of plastic packaging waste resulting from those products. A different approach for saving resources is instead applied to paints and varnishes, where a minimum spreading rate is set $\left(\mathrm{L} / \mathrm{m}^{2}\right)$. Lightweighting requirements have not been developed so far for more complex products. This would require the comparison of different materials and design options and the

Table 3 Examples of material efficiency aspects linked to EU Ecolabel requirements

\begin{tabular}{|c|c|}
\hline Strategy & Options \\
\hline Reduction & $\begin{array}{l}\text { Use of material resources in products: } \\
\text { Design optimisation and lightweighting } \\
\text { Selection and sourcing of resources (e.g. critical raw materials) } \\
\text { Manufacturing process: } \\
\text { Efficiency in the use of materials } \\
\text { Minimisation of manufacturing waste }\end{array}$ \\
\hline Reuse & $\begin{array}{l}\text { Durability: } \\
\text { Stress resistance } \\
\text { Endurance } \\
\text { Reliability } \\
\text { Extended guarantee } \\
\text { Provision of information about use and maintenance } \\
\text { Reparability, Reusability and Upgradability (RRU): } \\
\text { Product design (e.g. ease of disassembly of target parts) } \\
\text { Spare parts availability } \\
\text { Upgradability } \\
\text { Data transfer and deletion functionalities } \\
\text { Provision of repair, reuse and upgrade information }\end{array}$ \\
\hline Recycling/recovery & $\begin{array}{l}\text { Recyclability: } \\
\text { Recyclability thresholds } \\
\text { Restrictions on substances/materials hampering recycling } \\
\text { Marking of materials/parts } \\
\text { Ease of dismantling of target parts and provision of instruction } \\
\text { Information on the presence of specific substances in the product (e.g. hazardous substances) } \\
\text { Recycled content: } \\
\text { Minimum content of recycled materials } \\
\text { Take-back systems }\end{array}$ \\
\hline
\end{tabular}


assessment of the related trade-offs. Setting fair thresholds that do not limit or penalise future technical solutions is not straightforward.

Requirements related to waste minimisation focus on waste production rates at the factory. Waste production limits are set as a function of the production volume by weight and are nuanced for the type of product (e.g. $20 \%$ for envelopes in converted paper) or for the type of process (e.g. $23 \%$ for sheet offset printing, $10 \%$ for coldest newspaper printing and $15 \%$ for gravure printing).

No restrictions are usually applied to specific materials, although this could be explored in the future for critical raw materials (CRMs) and minerals from conflict-affected and high-risk areas (EC 2017j, 2017k). Only the reduction of sources of inherent hazardous substances is an aspect that is currently addressed in a systematic way through EU Ecolabel requirements (EC 2010).

\subsection{Reuse}

Material efficiency options currently implemented in EU Ecolabel requirements for this strategy typically address the durability, reparability, reusability and upgradability of products.

Durability aspects are predominantly associated with multi-use and long life products that could include complex articles (the more complex an article, the more parts that can break and render the entire product obsolete). Durability requirements mainly focus on resistance to stresses, for example, abrasion resistance for textile fabrics and furniture upholstery, resistance to indentation for wooden floor coverings, scratch resistance for coated furniture pieces, height and firmness endurance for bed mattresses and resistance to shock for data storage drives of computers.

Setting minimum thresholds on endurance and reliability over the lifetime of products is more challenging because of the difficulties associated with the testing and verification of such information. The actual effectiveness of such requirements should also cover functional aspects in order to account for loss of performance over time (Alfieri et al. 2018b), and be supported by appropriate testing procedures. So far, more advanced requirements in this area have been only set for computers.

Adequate product guarantees can be another manner to handle durability indirectly. In the EU Ecolabel this is required for batteries in notebooks (2 years), computers (3 years), furniture ( 5 years), wooden floor coverings ( 5 years) and mattresses (10 years).

Other requirements related to the reuse of products involve the incorporation of design features for the ease of disassembly of products, together with a commitment to make spare parts available and provide information on how to carry out maintenance and repairs. All three of these factors should be used together, and in a systematic way, in order to make re-use or repair a potential option in the real world. Although important for energy-related products and complex articles made of multiple materials and/or parts, these types of requirements are fundamentally irrelevant for other product groups, such as tissue paper and mixtures.

With respect to the spare parts, important issues are their availability, cost and delivery time over a sufficiently large period. For instance, the availability of spare parts after the purchase of the product must be 10 years for water-based heaters, 7 years for televisions, 5 years for computers, monitors and new furniture. Nevertheless, cost and time of delivery are not specified in any detail.

The energy-related products regulated in Ecolabel are examples of electrical and electronic equipment (EEE) that can at some point become obsolete. Especially for these products, the coverage of aspects related to reusability and upgradability (e.g. software and firmware update, deletion and transfer of personal data) are essential to avoid premature obsolescence, support the promotion of second hand markets, and prolong the product lifetime.

\subsection{Recycling/recovery}

Material efficiency options currently implemented in EU Ecolabel requirements for this strategy usually cover design aspects aimed to maximise the potential for recycling the product, so-called "design for recyclability".

For products which are complex articles, this inevitably relates to the ability to easily separate the product into different materials (e.g. metal, plastic, textiles and wood), which can require restrictions on substances, fulfilment of design characteristics and provision of information. Design approaches facilitating the ease of dismantling of EEE products into different parts (e.g. parts that are rich in valuable materials and/or hazardous substances and parts that are relatively low-value plastics) can also assist greatly the potential recovery of value from this waste stream. This can be assisted also through the marking of parts and materials, as done for plastics in computers.

For simple articles like paper products, this is not practical except when the paper article is printed or converted, because only then choices can be made that affect the product recyclability (e.g. degree of varnish or lamination applied and type of inks used). With product groups that are mixtures, the design for recyclability is mainly focused on the choice and combination of polymers in plastic packaging, labels and sleeves.

Moreover, minimum thresholds on recycled content are sometimes required for specific materials, based on technical and market conditions. Examples are the minimum $10 \%$ average post-consumer plastic required in computers (except circuit boards and display optical plastics), the minimum $30 \%$ average plastic-recycled content in furniture (if plastic 
accounts for at least $20 \%$ of furniture product weight), the minimum $70 \%$ recycled paperboard in packaging for hard coverings. However, an optional approach is taken in some cases, for instance, when dealing with requirements for wood (relevant to the paper products, furniture and footwear) where a requirement for at least $70 \%$ of sustainable wood/fibre content is set and where recycled wood or paper is considered equivalent to virgin wood or fibres from sustainably managed forests for this purpose.

It could be argued that the incorporation of recycled material also constitutes a material reduction (on virgin material consumption). However, requirements on the recycled content of a certain material work when there is sufficient supply of that recycled material. For instance, minimum recycled content for paper has not been required in the EU Ecolabel for graphic paper and tissue paper based on the argument that waste paper demand already exceeds market supply. Similar considerations apply to metals (e.g. in furniture).

When the market of a certain recycled material needs to be stimulated, it could be more appropriate to quantify recyclability targets for such material. However, requirements in this direction have not been set so far in the EU Ecolabel criteria (they are currently under discussion for some products). Moreover, from a life cycle perspective, the distance between recycling plants and manufacturers is also relevant, as the environmental impacts due to long-distance transport could counterbalance the potential benefits of recycling. Blengini and Garbarino (2010) estimated that the use of recycled aggregates (when compared to natural aggregates) can remain environmentally beneficial up until the point when the transport distance for recycled aggregates becomes $2-3$ times longer than that for natural aggregates.

Another important aspect refers to the potential presence of hazardous substances which can hamper the recycling of materials. Articles 6(6) and 6(7) of the EU Ecolabel Regulation (EC 2010) specifically exclude the awarding of the EU Ecolabel to goods that contain certain hazardous substances, including Substances of Very High Concern (SVHCs). Articles 7 and 33 of the REACH Regulation (EC 2006b) oblige suppliers and manufacturers to inform their downstream customers upon request if the content of any individual SVHC exceeds $0.10 \%$ by weight in any article they supply. Although it is legal to sell products on the EU market that contain SVHCs in concentrations exceeding $0.10 \%$, such products would not qualify for the EU Ecolabel. It is a significant challenge for producers who buy virgin materials and chemicals to ensure continued compliance with customer requests for SVHC information on their products. However, when dealing with recycled inputs there are some major doubts about legacy substances that may be present (e.g. creosote in recycled wood and cadmium or lead in recycled PVC). Testing protocols may exist for a few individual substances in specific materials but this cannot be extended to all
SVHCs and cannot be applied to each batch (e.g. of recycled plastic) that is delivered. The two extremes of possible approaches are

1. To treat recycled materials in the same way as virgin materials and effectively prevent the recycling of materials due to excessive testing costs. This is a restrictive approach that would penalise recycled materials in the short to medium term. However, all legacy restricted compounds will sooner be removed entirely from material loops.

2. To not place any particular restrictions on the recycled materials, to promote their use. Legacy-restricted compounds could gradually diminish over time at a sectorial level.

These two extremes each have their own advantages and disadvantages and serve to highlight a potential source of discrepancy in EU initiatives (i.e. the Circular Economy Action Plan and the EU Ecolabel). The most appropriate option, while being inevitably somewhere in the middle, will depend on the nature of the substance, the type of use of relevant articles and the exposure risk that exists to users or the wider environment.

Finally, with the notable exception of water-based heaters, the promoted take-back systems focus on business to business relationships (i.e. return of packaging of industrial/ institutional cleaning products or collection of growing media from professional horticultural applications). The take-back of water-based heaters could be of considerable interest to producers in any case due to the potential to cannibalise old products for spare parts and facilitate repair operations elsewhere.

\subsection{Possible trade-offs and limitations in the definition of material efficiency requirements}

The development of material efficiency requirements should be supported by a solid evidence basis. LCA is a key tool for understanding which design options can be more beneficial from an environmental perspective and if relevant trade-offs exist.

In theory, availability of information for a statistically representative sample of products could allow for the definition of environmental thresholds based on life cycle indicators. However, the state-of-the-art is that this approach presents limitations such as a wide variety of product designs, qualities and functionalities on the market that lie within the same product group scope; lack of available primary or even secondary data; evolving LCA methods and tools and the associated uncertainty; low availability of robust and fair assessment and verification procedures and the duration of the criteria development process. Furthermore, other considerations are also important in order to understand the economic, 
social and market consequences for particular products, materials or sectors. Benefits and any trade-offs associated with different material efficiency options can be assessed adopting a practical life cycle thinking (LCT) approach based on LCA and complemented by other product-related information (Cordella and Wolf 2015).

All material-based products have an inherently physical limit for lightweighting. Although lightweighting could bring direct and quantifiable environmental benefits from an LCA perspective, this should be considered in the context of the overall impacts of functionally equivalent products. For example, substituting a 10-kg set of steel table legs for a 6-kg set of aluminium table legs, with the fulfilment of the same technical specifications, may actually increase the overall environmental impacts of the table if virgin aluminium is used instead of virgin steel (Norgate et al. 2007). Further variations may depend on any recycled content allocated to the steel or aluminium used. Moreover, additional limitations to lightweighting may be associated with the need of fulfilling minimum technical specifications for product safety, performance and durability.

There can be trade-offs also between recycled content and safety or technical performance. For example, with a safety first approach, there is the tendency that bags, components or products made predominantly from recycled plastic (EC 2015d) will be thicker or bulkier to compensate for doubts about batch consistency that may impact on the physical properties of the product. This was one of the main reasons why the packaging efficiency requirements set for EU Ecolabel cleaning products did not apply if the recycled content exceeded $80 \%$.

Moreover, the effects of alternative options should be assessed taking into account market evolution. Depending on the relative magnitudes of impacts due to production, use phase and end of life, it could be either more convenient to prolong the use of energy-related products or to replace them with more efficient products (Alfieri et al. 2018a; Cordella et al. 2018; Iraldo et al. 2017; Tecchio et al. 2016).

Finally, in some circumstances, actions that improve the durability of a product (e.g. gluing) could have consequences at material level and/or compromise reparability. The EU Ecolabel tends to focus on the extent to which design features have been incorporated into products that would make interventions as reuse, repair and refurbishment as feasible as possible in the future.

\section{Cross-check of material efficiency aspects with EU policies and initiatives}

From Table 2, it is clear that every EU Ecolabel product group has some requirements on material efficiency. When considering interactions between the EU Ecolabel and other EU policies and initiatives (see Table 4), different types of relationships can be categorised:

I. Market-focused symbiosis (see also Fig. 1): In this case, the EU Ecolabel can act as a flagship policy to promote material efficiency front-runners with a supply side signal. The same material efficiency aspects can be addressed in a similar way in GPP (EC 2008b) and Ecodesign (EC 2009a), although at a different ambition level. When applicable, the mandatory nature of the Ecodesign Directive obliges producers to place on the market products that fulfil minimum requirements. The GPP policy tool, when setting relevant material efficiency criteria, instead sends a demand side signal and has the flexibility to set less ambitious requirements than the EU Ecolabel (especially via "core level" technical specifications) but reward more efficient products (via award criteria). Communication of material efficiency aspects could be potentially integrated also in the Energy Label (EC 2017a).

II. Policy synergies: These are the case when any promotion of material efficiency in the EU Ecolabel is well aligned with the general objectives of other policies and initiatives, in a way that the application of one compliments the objectives of the other. In general, the material efficiency aspects discussed in this analysis are addressed through the Circular Economy Action Plan (EC 2015a). As presented earlier, this is a major policy effort to promote the durability and reparability of products and other design side aspects such as selection of materials, recyclability and the incorporation of recycled content into products. From a narrower perspective, the Waste Framework Directive (EC 2008c, 2018a) is arguably the most closely related with material efficiency in this respect, as highlighted in Fig. 3, and is sufficiently broad to apply to all EU Ecolabel product groups. The Packaging Directive (EC 1994) and the WEEE Directive (EC 2012b) also have mutually inclusive objectives but are limited in scope to packaging and electronic/ electrical equipment respectively. However, there are other areas where EU policies and initiatives can serve as potential source of inspiration for the EU Ecolabel, such as CRMs and conflict minerals (EC 2017j, 2017k), due to the geopolitically sensitive issues involved in their supply, as well as batteries (EC 2006c) and vehicles (EC 2000, 2005b, 2011c), for the management of hazardous substances and the correct disposal, collection and recycle of products and the setting of RRR targets.

III. Checks and balances: These are examples of policies and initiatives that can put a practical limit to material efficiency or that assess what the effect of changing the material efficiency is on overall environmental impacts. Concerns about hazardous substances in recycled material streams present a significant barrier to any 
Table 4 Policies and legislation linked to EU Ecolabel material efficiency requirements and included in the analysis

Policy/initiative and possible interactions with the EU Ecolabel

Market-focussed symbiosis

Policy synergies

Checks and balances

(EC 2004,2006

2011a): CLP and REACH are the two key elements referred to in the implementation of Articles 6.6 and 6.7 of the EU Ecolabel Regulation, which foresees the restrictions on chemicals based on their hazardous properties. Additional legislation addresses specific products, such as RoHS for EEE. Restrictions on hazardous materials may facilitate the recycling process but may also present a barrier to the incorporation of recycled materials in new products.

Consumer Sales Directive (EC 1999, 2011b): ensures a minimum guarantee of 2 years in all EU Member States for consumer goods and repair or replacement if goods are faulty. It indirectly encourages more durable goods that can be taken back and repaired if necessary. The EU Ecolabel requirements promote similar types of guarantees but for longer periods. A longer guarantee is a kind of proxy for better durability.

PEF (EC 2013a): sets common rules for LCA assessment of defined product groups. Could be used to assess the importance of any material efficiency aspects on the environmental footprint of the product and to potentially identify unexpected trade-offs that may occur via the promotion of material efficiency (e.g. lightweighting via substitution of one material for another).

In addition, the analysis also include the Circular Economy Action Plan (EC 2015a), legislation on safety (EC 2001, 2006a, 2014h), hazardous substances (EC 2004, 2006b, 2008d, 2011a), consumer rights (EC 1999, 2011b) and product end of life (EC 2008c, 2012b, 2018a), and more specific product-related topics (packaging (EC 1994), priority materials (EC 2017j, 2017k), batteries (EC 2006c) and vehicles (EC 2000, 2005b, 2011c)) 
mandatory requirement for recycled content in EU Ecolabel products (see section 3.3 for more details). Material efficiency in product design should not be prioritised over product safety or functionality. Even for products where clear safety or fitness for use standards have not been defined, the General Products Safety Directive (EC 2001) and the Consumer Rights Directives (EC 2011b) still applies, as well as legislation on hazardous substances (EC 2004, 2006b, 2008d, 2011a). Although improved material efficiency can be generally perceived as being associated with environmental benefits, simple metrics (e.g. the content of recycled material) could lead to unexpected outcomes. In this respect, the application of an LCA approach, such as the Product Environmental Footprint (EC 2013a), could help to better understand possible trade-offs in such situations.

\section{Conclusions}

An overview of material efficiency aspects addressed in voluntary EU Ecolabel criteria for 26 different product groups has been presented in the context of a classification system based on a hierarchy of strategies: reduction, reuse and recycling/ recovery. The main findings are

1. Reduction: Requirements for lightweighting have been mainly limited to packaging of mixtures and not to products due to the major difficulty of defining thresholds for the material design of products. For some products, the reduction option also addresses the amount of waste generated in the production plant.

2. Reuse: Durability of products in terms of resistance to stresses has been broadly implemented. A higher durability can extend the useful lifetimes of products, with potential benefits for consumers and the environment. Product lifetime extensions should not come at the expenses of functional losses and should be backed up by suitable testing procedures and/or guarantees. Although not examined in detail in this work, fitness for use requirements are set systematically in the EU Ecolabel, which somehow address the functionality of products and can prevent overconsumption or the premature replacement of products. Repair, reuse and upgrade of products are also addressed in products which are articles. To be enabled, they need to be backed up by appropriate requirements on product design, availability of spare parts and provision of clear information. Upgradability becomes in particular important for quickly developing products as ICT devices.
3. Recycling/recovery: Although being identified as the lowest priority material efficiency strategy, requirements associated with the recycling of products are the most commonly implemented across EU Ecolabel product groups. These mainly focus on the ease of dismantling of products in such a way that target parts can be easily extracted from the product. Requirements that promote the incorporation of recycled content into EU Ecolabel are hindered due to concerns about recyclate batch consistency and the requirements of Articles 6(6) and 6(7) of the EU Ecolabel Regulation. Quantitative targets on the recyclability and recoverability of materials could be explored to stimulate the market for some recycled materials.

The analysis of how material efficiency aspects can interact between different policies has shown that the promotion of material efficiency in the EU Ecolabel is complementary with a number of other EU policies and initiatives. Areas where similarities and synergies between different policies could be exploited have been identified, as well as barriers limiting the possibilities to improve the material efficiency of products.

This analysis of material efficiency aspects can serve as a reference base for a coherent implementation of relevant EU policies and future Ecolabel criteria. Furthermore, it can also support research activities relating to the development of design concepts, common language and relevant technical standards which aims to promote material efficiency in products and the circular economy. Such developments should also aim to quantify the expected impacts from any material efficiency measures set in different policy tools/labels. For any quantitative data, LCA is the key tool to understand potential environmental benefits and associated trade-offs. However, other political, technical and socio-economic considerations also need to be considered to ensure the feasibility of such measures.

Acknowledgments The authors would like to thank the JRC B.5 staff working on the implementation of Sustainable Product Policy tools for aiding in the identification of product-specific requirements on material efficiency aspects.

Funding information The authors are grateful to the European Commission for financing this work through the Administrative Agreement N. 070201/2015/SI2.719458/ENV.A.1 signed by DG ENV and DG JRC.

\section{Compliance with ethical standards}

Disclaimer The opinions expressed in this manuscript are purely those of the authors and may not in any circumstances be regarded as stating an official position of the European Commission.

Open Access This article is distributed under the terms of the Creative Commons Attribution 4.0 International License (http:// 
creativecommons.org/licenses/by/4.0/), which permits unrestricted use, distribution, and reproduction in any medium, provided you give appropriate credit to the original author(s) and the source, provide a link to the Creative Commons license, and indicate if changes were made.

\section{References}

Alfieri F, Cordella M, Sanfelix J, Dodd N (2018a) An approach to the assessment of durability of energy-related products. Proc CIRP 69: 878-891

Alfieri F, Cordella M, Stamminger R, Bues A (2018b) Durability assessment of products: analysis and testing of washing machines , EUR 29487 EN, Publications Office of the European Union, Luxembourg, ISBN 978-92-79-98136-4, doi:https://doi.org/10. $2760 / 115684$

Allwood JM, Ashbya MF, Gutowski TG, Worrell E (2011) Material efficiency: a white paper. Resour Conserv Recycl 55:362-381

Bakker C, Wang F, Huisman J, den Hollander M (2014) Products that go round: exploring product life extension through design. J Clean Prod 69:10-16

Blengini GA, Garbarino E (2010) Resources and waste management in Turin (Italy): the role of recycled aggregates in the sustainable supply mix. J Clean Prod 18:1021-1030

CEN/CLC/JTC 10 (2019) Energy-related products - Material efficiency aspects for ecodesign. https://www.cenelec.eu/dyn/www/f?p=104: 7:1299206399119101::::FSP ORG ID:2240017. Accessed 26 Feb 2019

Cordella M, Hidalgo C (2016) Analysis of key environmental areas in the design and labelling of furniture products: application of a screening approach based on a literature review of LCA studies. Sustain Prod Consum 8:64-77

Cordella M, Wolf O (2015) Sustainable Product Policies and LCA: experience gained from the development of environmental labelling criteria Proceedings of the SETAC Europe 25th annual meeting, Barcelona (Spain)

Cordella M, Tugnoli A, Barontini F, Spadoni G, Cozzani V (2009) Inherent safety of substances: identification of accidental scenarios due to decomposition products. J Loss Prevent Proc 22:455-462

Cordella M, Torri C, Adamiano A, Fabbri D, Barontini F, Cozzani V (2012) Bio-oils from biomass slow pyrolysis: a chemical and toxicological screening. J Hazard Mater 231-232:26-35

Cordella M, Bauer I, Lehmann A, Schulz M, Wolf O (2015) Evolution of disposable baby diapers in Europe: life cycle assessment of environmental impacts and identification of key areas of improvement. J Clean Prod 95:322-331

Cordella M, Sanfelix J, Alfieri F (2018) Development of an approach for assessing the reparability and upgradability of energy-related products. Proc CIRP 69:888-892

EC (1994) European Parliament and Council 94/62/EC of 20 December 1994 on packaging and packaging waste. OJ L 365, 31.12.1994, pp10-23

EC (1999) Directive 1999/44/of the European Parliament and of the Council of 25 May 1999 on certain aspects of the sale of consumer goods and associated guarantees. OJ L 171, 7.7.1999, pp 12-16

EC (2000) Directive 2000/53/EC of the European Parliament and of the Council of 18 September 2000 on end of life vehicles. OJ L 269, 21.10.2000, pp $34-43$

EC (2001) Directive 2001/95/EC of the European Parliament and of the Council of 3 December 2001 on general product safety. OJ L 11, 15.1.2002, pp 4-17
EC (2003) Communication from the Commission to the Council and the European Parliament, Integrated Product Policy, Building on Environmental Life-Cycle Thinking, COM/2003/0302 final

EC (2004) Regulation (EC) No 850/2004 of the European Parliament and of the Council of 29 April 2004 on persistent organic pollutants and amending Directive 79/117/EEC. OJ L 158, 30.4.2004, pp 7-49

EC (2005a) Directive 2005/32/EC of the European Parliament and of the Council of 6 July 2005 establishing a framework for the setting of ecodesign requirements for energy-using products and amending Council Directive 92/42/EEC and Directives 96/57/EC and 2000/55/EC of the European Parliament and of the Council

EC (2005b) Directive 2005/64/EC of the European Parliament and of the Council of 26 October 2005 on the type-approval of motor vehicles with regard to their reusability, recyclability and recoverability and amending Council Directive 70/156/EEC. OJ L 310, 25.11.2005, p.10-27

EC (2006a) Directive 2006/42/EC of the European Parliament and of the Council of 17 May 2006 on machinery, and amending Directive 95/ 16/EC. OJ L 157, 9.6.2006, p. 24-86

EC (2006b) Regulation (EC) No 1907/2006 of the European Parliament and of the Council of 18 December 2006 concerning the Registration, Evaluation, Authorisation and Restriction of Chemicals (REACH), establishing a European Chemicals Agency, amending Directive 1999/45/EC and repealing Council Regulation (EEC) No 793/93 and Commission Regulation (EC) No 1488/94 as well as Council Directive 76/769/EEC and Commission Directives 91/155/EEC, 93/67/EEC, 93/105/EC and 2000/21/EC. OJ L 396, 30.12 .2006 , p. $1-849$

EC (2006c) Directive 2006/66/EC of the European Parliament and of the Council of 6 September 2006 on batteries and accumulators and waste batteries and accumulators and repealing Directive 91/157/ EEC. OJ L 266, 26.9.2006, pp 1-14

EC (2008a) Communication from the Commission to the European Parliament, the Council, the European Economic and Social Committee and the Committee of the Regions on the Sustainable Consumption and Production and Sustainable Industrial Policy Action Plan COM/2008/0397 final

EC (2008b) Communication from the Commission to the European Parliament, the Council, the European Economic and Social Committee and the Committee of the Regions. Public procurement for a better environment. COM/2008/0400 final

EC (2008c) Directive 2008/98/EC of the European Parliament and of the Council of 19 November 2008 on waste and repealing certain Directives. OJ L 312, 22.11.2008, pp 3-30

EC (2008d) Regulation (EC) No 1272/2008 of the European Parliament and of the Council of 16 December 2008 on classification, labelling and packaging of substances and mixtures, amending and repealing Directives 67/548/EEC and 1999/45/EC, and amending Regulation (EC) No 1907/2006. OJ L 353, 31.12.2008, pp 1-1355

EC (2009a) Directive 2009/125/EC of the European Parliament and of the Council of 21 October 2009 establishing a framework for the setting of ecodesign requirements for energy-related products. OJ L 285 , 31.10.2009, pp 10-35

EC (2009b) Commission Decision 2009/300/EC establishing the revised ecological criteria for the award of the Community Eco-label to televisions. OJ L 82, 28.3.2009, pp 3-8

EC (2009c) Commission Decision 2009/607/EC of 9 July 2009 establishing the ecological criteria for the award of the Community ecolabel to hard coverings. OJ L 208, 12.8.2009, pp 21-38

EC (2010) Regulation (EC) No 66/2010 of the European Parliament and of the Council of 25 November 2009 on the EU Ecolabel. OJ L 27, 30.1.2010, pp 1-19

EC (2011a) Directive 2011/65/EU of the European Parliament and of the Council of 8 June 2011 on the restriction of the use of certain hazardous substances in electrical and electronic equipment. OJ L 174 , 1.7.2011, pp 88-110 
EC (2011b) Directive 2011/83/EU of the European Parliament and of the Council of 25 October 2011 on consumer rights, amending Council Directive 93/13/EEC and Directive 1999/44/EC of the European Parliament and of the Council and repealing Council Directive 85/ 577/EEC and Directive 97/7/EC of the European Parliament and of the Council. OJ L 304, 22.11.2011, pp 64-88

EC (2011c) Commission Regulation (EU) No 566/2011 of 8 June 2011 amending Regulation (EC) No 715/2007 of the European Parliament and of the Council and Commission Regulation (EC) No 692/2008 as regards access to vehicle repair and maintenance information. OJ L 158, 16.6.2011, pp 1-24

EC (2012a) Directive 2012/27/EU of the European and the of the Council of 25 October 2012 on energy efficiency, amending Directives 2009/125/EC and 2010/30/EU and repealing Directives 2004/8/EC and 2006/32/EC. OJ L 315, 14.11.2012, pp 1-56

EC (2012b) Directive 2012/19/EU of the European Parliament and of the Council of 4 July 2012 on waste electrical and electronic equipment (WEEE). OJ L 197, 24.7.2012, pp 38-71

EC (2012c) Commission Decision 2012/481/EU of 16 August 2012 establishing the ecological criteria for the award of the EU Ecolabel for printed paper. OJ L 223, 21.8.2012, pp 55-65

EC (2012d) Commission Decision 2012/448/EU of 12 July 2012 establishing the ecological criteria for the award of the EU Ecolabel for newsprint paper. OJ L 202, 28.7.2012, pp 26-37

EC (2013a) Commission Recommendation 2013/179/EU of 9 April 2013 on the use of common methods to measure and communicate the life cycle environmental performance of products and organisations. OJ L 124, 4.5.2013, pp 1-210

EC (2013b) Communication from the Commission to the European Parliament and the Council, Building the Single Market for Green Products ' Facilitating better information on the environmental performance of products and organisations. COM/2013/0196 final

EC (2014a) Commission Decision 2014/314/EU establishing the criteria for the award of the EU Ecolabel for water-based heaters, OJ L 164, 3.6.2014, pp 83-103

EC (2014b) Commission Decision 2014/763/EU establishing the ecological criteria for the award of the EU Ecolabel for absorbent hygiene products. OJ L 320, 6.11.2014, pp 46-63

EC (2014c) Commission Decision of 23 June 2014 establishing the ecological criteria for the award of the EU Ecolabel for bed mattresses. OJ L 184, 25.6.2014, pp 18-48

EC (2014d) Commission Decision 2014/350/EU of 5 June 2014 establishing the ecological criteria for the award of the EU Ecolabel for textile products. OJ L 174, 13.6.2014, pp 45-83

EC (2014e) Commission Decision 2014/256/EU of 2 May 2014 establishing the ecological criteria for the award of the EU Ecolabel for converted paper products. OJ L 135, 8.5.2014, pp 24-48

EC (2014f) Commission Decision, 2014/312/EU establishing the ecological criteria for the award of the EU Ecolabel for indoor and outdoor paints and varnishes. OJ L 164, 3.6.2014, pp 45-73

EC (2014g) Commission Decision 2014/893/EU of 9 December 2014 establishing the ecological criteria for the award of the EU Ecolabel for rinse-off cosmetic products. OJ L 354, 11.12.2014, pp 47-61

EC (2014h) Directive 2014/35/EU of the European Parliament and of the Council of 26 February 2014 on the harmonisation of the laws of the Member States relating to the making available on the market of electrical equipment designed for use within certain voltage limits. OJ L 96, 29.3.2014, pp 357-374

EC (2015a) Communication from the Commission to the European Parliament, the Council, the European Economic and Social Committee and the Committee of the Regions. Closing the loop An EU action plan for the Circular Economy. COM/2015/0614 final

EC (2015b) M/543 Commission Implementing Decision C(2015)9096 of 17.12.2015 on a standardisation request to the European standardisation organisations as regards ecodesign requirements on material efficiency aspects for energy-related products in support of the implementation of Directive 2009/125/EC of the European Parliament and of the Council

EC (2015c) Commission Decision (EU) 2015/2099 of 18 November 2015 establishing the ecological criteria for the award of the EU Ecolabel for growing media, soil improvers and mulch. OJ L 303, 20.11.2015, pp 75-100

EC (2015d) Directive (EU) 2015/720 of the European Parliament and of the Council of 29 April 2015 amending Directive 94/62/EC as regards reducing the consumption of lightweight plastic carrier bags. OJ L 115, 6.5.2015, pp 11-15

EC (2016a). Commission Decision (EU) 2016/1371 establishing the ecological criteria for the award of the EU Ecolabel for personal, notebook and tablet computers. OJ L 217, 12.8.2016, pp 9-37

EC (2016b) Commission Decision (EU) 2016/1349 of 5 August 2016 establishing the ecological criteria for the award of the EU Ecolabel for footwear. OJ L 214, 9.8.2016, pp 16-52

EC (2016c) Commission Decision (EU) 2016/1332 of 28 July 2016 establishing the ecological criteria for the award of the EU Ecolabel for furniture. OJ L 210, 4.8.2016, pp 100-149

EC (2017a) Regulation (EU) 2017/1369 of the European Parliament and of the Council of 4 July 2017 setting a framework for energy labelling and repealing Directive 2010/30/EU. OJ L 198, 28.7.2017, pp $1-23$

EC (2017b) Commission Decision (EU) 2017/176 of 25 January 2017 on establishing EU Ecolabel criteria for wood-, cork- and bamboobased floor coverings. OJ L 28, 2.2.2017, pp 44-68

EC (2017c) Commission Decision (EU) 2017/1216 of 23 June 2017 establishing the EU Ecolabel criteria for dishwasher detergents. OJ L 180, 12.7.2017, pp 31-44

EC (2017d) Commission Decision (EU) 2017/1214 of 23 June 2017 establishing the EU Ecolabel criteria for hand dishwashing detergents. OJ L 180, 12.7.2017, pp 1-15

EC (2017e) Commission Decision (EU) 2017/1217 of 23 June 2017 establishing the EU Ecolabel criteria for hard surface cleaning products. OJ L 180, 12.7.2017, pp 45-62

EC (2017f) Commission Decision (EU) 2017/1215 of 23 June 2017 establishing the EU Ecolabel criteria for industrial and institutional dishwasher detergents. OJ L 180, 12.7.2017, pp 16-30

EC (2017g) Commission Decision (EU) 2017/1219 of 23 June 2017 establishing the EU Ecolabel criteria for industrial and institutional laundry detergents. OJ L 180, 12.7.2017, pp 79-96

EC (2017h) Commission Decision (EU) 2017/1218 of 23 June 2017 establishing the EU Ecolabel criteria for laundry detergents. OJ L $180,12.7 .2017$, pp $63-78$

EC (2017i) Commission Decision (EU) 2017/175 of 25 January 2017 on establishing EU Ecolabel criteria for tourist accommodation. OJ L 28, 2.2.2017, pp 9-43

EC (2017j) Communication from the Commission to the European Parliament, the Council, the European Economic and Social Committee and the Committee of Regions on the 2017 list of Critical Raw Materials for the EU. COM/2017/0490 final

EC (2017k) Regulation (EU) 2017/821 of the European Parliament and of the Council of 17 May 2017 laying down supply chain due diligence obligations for Union importers of tin, tantalum and tungsten, their ores, and gold originating from conflict-affected and high-risk areas, OJ L 130, 19.5.2017, pp 1-20

EC (2018a) Directive (EU) 2018/851 of the European Parliament and of the Council of 30 May 2018 amending Directive 2008/98/EC on waste. OJ L 150, 14.6.2018, pp 109-140

EC (2018b) DG Environment EU Ecolabel official website: Facts and figures, http://ec.europa.eu/environment/ecolabel/facts-and-figures. html (Accessed 30 Sept 2018)

EC (2018c) Commission Decision (EU) 2018/1702 of 8 November 2018 establishing the EU Ecolabel criteria for lubricants, OJ L 285, 13.11.2018, pp 82-96 
EC (2018d) Commission Decision (EU) 2018/680 of 2 May 2018 establishing EU Ecolabel criteria for indoor cleaning services. OJ L 114, 4.5.2018, pp 22-38

EC (2019) Commission Decision (EU) 2019/70 of 11 January 2019 establishing the EU Ecolabel criteria for graphic paper and the EU Ecolabel criteria for tissue paper and tissue products, OJ L 15, 17.1.2019, pp 15-57

Ernst\& Young (1998) Integrated Product Policy, A study analysing national and international developments with regard to Integrated Product Policy in the environment field and providing elements for an EC policy in this area. Ernst\&Young report to the European Commission, March 1998, http://ec.europa.eu/environment/ipp/pdf/ ippsum.pdf (Accessed 26 Feb 2019)

Huysman S, Sala S, Mancini L, Ardente F, Alvarenga RAF, De Meester S, Mathieux F, Dewulf J (2015) Toward a systematized framework for resource efficiency indicators. Resour Conserv Recycl 95:68-76

Iraldo F, Barberio M (2017) Barriers and benefits of the EU Ecolabel in European companies' perception. Sustainability 9:751

Iraldo F, Facheris C, Nucci B (2017) Is product durability better for environment and for economic efficiency? A comparative assessment applying LCA and LCC to two energy-intensive products. J Clean Prod 140:1353-1364

ISO (2006a) International Organization for Standardization. ISO 14040: 2006 Environmental management — life cycle assessment — principles and framework
ISO (2006b) International Organization for Standardization. ISO 14044: 2006 Environmental management - life cycle assessment — requirements and guidelines

ISO (2018) ISO 14024:2018. Environmental labels and declarations - Type I environmental labelling - Principles and procedures

Norgate TE, Jahanshahi S, Rankin WJ (2007) Assessing the environmental impact of metal production processes. J Clean Prod 15:838-848

Russell JD (2018) Market transformation for value-retention processes as a strategy for circular economy. Thesis, Rochester Institute of Technology. https://scholarworks.rit.edu/theses/9858 . Accessed 26 Feb 2019

Tecchio P, Ardente F, Mathieux F (2016) Analysis of durability, reusability and reparability - application to washing machines and dishwashers, publications Office of the European Union, EUR 28042 EN, https://doi.org/10.2788/630157

Traverso M, Wagner V, Trouvay B, Kluge J, Geckeler F (2013) A comprehensive approach of sustainability assessment of product in the automobile sector: challenges and benefits Proceedings of the 6th International Conference on Life Cycle Management - LCM 2013, Gothenburg (Sweden)

Publisher's note Springer Nature remains neutral with regard to jurisdictional claims in published maps and institutional affiliations. 